\title{
Lung donation after circulatory death
}

\author{
Laurens J. Ceulemans ${ }^{\mathrm{a}, \mathrm{b}, \mathrm{c}}$, Ilhan Inci ${ }^{\mathrm{c}}$, and Dirk Van Raemdonck ${ }^{\mathrm{a}, \mathrm{b}}$
}

\begin{abstract}
Purpose of review
The current review presents a concise update on published literature on donation after circulatory death (DCD) and lung transplantation (LTX). Worldwide an increasing need for lungs is evident, however the utilization rate of DCD lung donors is still considerably low. In this summary article, we reviewed both the experimental background and international clinical experience.
\end{abstract}

\begin{abstract}
Recent findings
Our analysis confirmed satisfactory results for $L T x$ from DCD donors, which equals the results from donation after brain death. Although most studies reported on short-erm results, some confirmed these results on the long-term and development of chronic lung allograft dysfunction. Our review summarizes the different $D C D$ categories and underlines the potential of the DCD V category. We analyze the barriers to implement a DCD program, discuss the more recent advances like ex-vivo lung perfusion and describe the future challenges.
\end{abstract}

\begin{abstract}
Summary
Based on the current short-term and long-term clinical results, we believe that barriers for DCD utilization should be overcome, resulting in a safe implementation of more DCD LTx programs worldwide.
\end{abstract}

Video abstract

http://links.Iww.com/MOT/A23

Keywords

donation after circulatory death, lung transplantation, organ donation

\section{INTRODUCTION}

Lung transplantation (LTx) activity increases worldwide $\left[1^{-}, 2^{\mathbf{}}\right]$. Although the number of lungs transplanted per donor reached 0.4 , we are still faced with a waiting-list mortality of $10 \%$ - according the Organ Procurement and Transplantation Network (OPTN) $\left[1^{-1}-3^{\prime}\right]$. Optimization of the donor pool should therefore be granted priority, leading to an increased interest in donation after circulatory death (DCD) [4-6]. It was shown that universal identification of potential DCD donors could increase LTx activity by $50 \%$, which would result in a virtual elimination of the waiting-list [7]. Although countries like the United Kingdom, Australia, Belgium and the Netherlands reached a high percentage of DCD donors, a continuous global underutilization is noticed $[5,8,9]$. In 2018 , the OPTN reported that only $6.6 \%(n=169)$ of all LTx $(n=2542)$ came from DCD, within Eurotransplant DCD utilization accounted for $5 \%(n=62)$ of all LTx in $2017(n=1233)[10,11]$. The latter could be explained by some countries (e.g. Germany) which have no legal framework to allow DCD [12]. Over the last years, several centers have reported their experience showing equal short-term and long-term outcome following LTx when comparing DCD with donation after brain death (DBD) $\left[9,13-23,24^{*}, 25\right.$, $\left.26^{*}, 27,28,29^{-"}\right]$.

In this review article, we summarize the historical background, definitions and current evidence for DCD and review the growing clinical experience. We discuss the recent advances in the field and future challenges.

\section{HISTORY OF DONATION AFTER CIRCULATORY DEATH}

The first donor used for clinical LTx died from a myocardial infarction and was a DCD donor [30]. Since then, definitions for brain-death were established and only donors who met brain-death criteria

${ }^{a}$ Department of Thoracic Surgery, University Hospitals Leuven, ${ }^{b}$ DepartDepartment of Chronic Diseases, Metabolism and Ageing, KU Leuven, Leuven, Belgium and ${ }^{\mathrm{C}}$ Department of Thoracic Surgery, University Hospital Zürich, Zürich, Switzerland

Correspondence to Laurens J. Ceulemans, MD, PhD, Department of Thoracic Surgery, University Hospitals Leuven, Herestraat 49, B-3000 Leuven, Belgium. Tel: +32 16346820; fax: +32 16346821;

e-mail: laurens.ceulemans@uzleuven.be

Curr Opin Organ Transplant 2019, 24:000-000

DOI:10.1097/MOT.0000000000000627 


\section{KEY POINTS}

- DCD lung donation cannot be denied in countries with existing legal framework.

- LTx from controlled DCD donors results in the same short-term and mid-term outcome as donation after brain death donors.

- Future research on long-term outcome and a detailed analysis of the agonal phase is needed.

were accepted. In 1991, Egan et al. [31] renewed the interest in the potential of DCD donors with a canine model of LTx and in 1995 D'Alessandro et al. reported the first modern and successful LTX as part of their institutional DCD program [32,33]. In a landmark publication by Steen et al. in 2001 a successful single-LTx was reported from a donor after failed cardiac resuscitation, which is defined as uncontrolled DCD (uDCD) [34], utilizing $17 \mathrm{~h}$ of ex-vivo lung perfusion (EVLP) for graft evaluation. Since then several centers have embraced DCD for successful expansion of their donor pool.

\section{THE LUNG IS AN AIRBAG FILLED WITH OXYGEN AND THEREFORE PRIVILEGED TO SUSTAIN ISCHEMIA}

The main concern regarding DCD is the warm ischemic time (WIT) between withdrawal of life-sustaining therapy (WLST) and procurement $[6,35,36]$. However, it has become apparent that the lungs are more robust to ischemia than first suspected. Actually, lung parenchyma is unique among all organs as it depends not solely on blood supply for its oxygenation and lung ischemia does not necessarily equate to tissue hypoxia [37]. In comparison with other organs, the lung has relatively low metabolic needs and is privileged by a local storage of oxygen in the alveoli. This was confirmed in a series of canine single-LTx in which the lung was retrieved at different time points after death and the contralateral pulmonary artery and bronchus were ligated after single-LTx, forcing the animals to survive solely on the transplanted DCD lung [31]. In another series of rat DCD experiments, it was found that lung cell death was delayed by postmortem mechanical ventilation with oxygen $[38,39]$. In a series of pig experiments, the Leuven group showed that up to 60-min WIT with the lung collapsed was tolerated with a similar graft function as in nonischemic lungs [40]. They also showed that prevention of alveolar collapse appears to be the critical factor in protecting the warm ischemic lung from reperfusion injury independent of continuous oxygen supply [41]. Recently, it was shown in pigs that hypoxic cardiac arrest, followed by 60,90 or $120 \mathrm{~min}$ of ischemia and normothermic 4-h EVLP did not result in differences between the groups regarding final oxygenation capacity, lung compliance, histological injury or wet-to-dry ratio, suggesting that longer WIT alone does not predict worse lung function [42"]. These findings may lead to an expansion of the acceptable WIT in clinical DCD procedures.

From a biological point of view, it is hypothesized that a brief WIT could even be beneficial due to the phenomenon of preconditioning [43]. Furthermore, DCD donation exclude the detrimental braindeath effect, which results in acute lung injury through a catecholamine storm, hemodynamic instability and systemic inflammation. It is associated with increased organ immunogenicity possibly due to the leukocyte-influx in the allograft $[44,45]$.

\section{DEFINITION OF DONATION AFTER CIRCULATORY DEATH TIMINGS}

The length of acceptable WIT is debatable, although most centers agree on 60-90 min [46"']. In 2008, Levvey defined WIT as the period between a drop of SBP less than $50 \mathrm{mmHg}$ and pulmonary artery flush. The International Society for Heart and Lung Transplantation (ISHLT) DCD working group recommended in 2015 six crucial time points in the DCD process (Fig. 1) [5,20].

The agonal phase is defined as the period between WLST and death declaration. Most centers accept a maximal period of $60-90 \mathrm{~min}$ and up to $180 \mathrm{~min}$ in Toronto [20]. Apart from a case report with an agonal phase of $120 \mathrm{~min}$, no clinical research was performed on this topic [47].

Since a recent analysis of the ISHLT DCD registry on 507 DCD LTx did not show a relationship between the duration of WIT or the agonal phase and early survival, the true limits of DCD utilization may not have been reached. That report showed that $84 \%$ of DCD organs used for LTx reached asystole within $30 \mathrm{~min}$ and $97 \%$ within $60 \mathrm{~min}$ post WLST [46"']. To better understand the impact of these different timings we suggest for future research to focus on the slope of mean arterial pressure and saturation and differentiate among relative, absolute and acirculatory WIT.

\section{DONATION AFTER CIRCULATORY DEATH CLASSIFICATION}

Originally, four DCD categories were defined according the Maastricht classification (Table 1) [48]. 


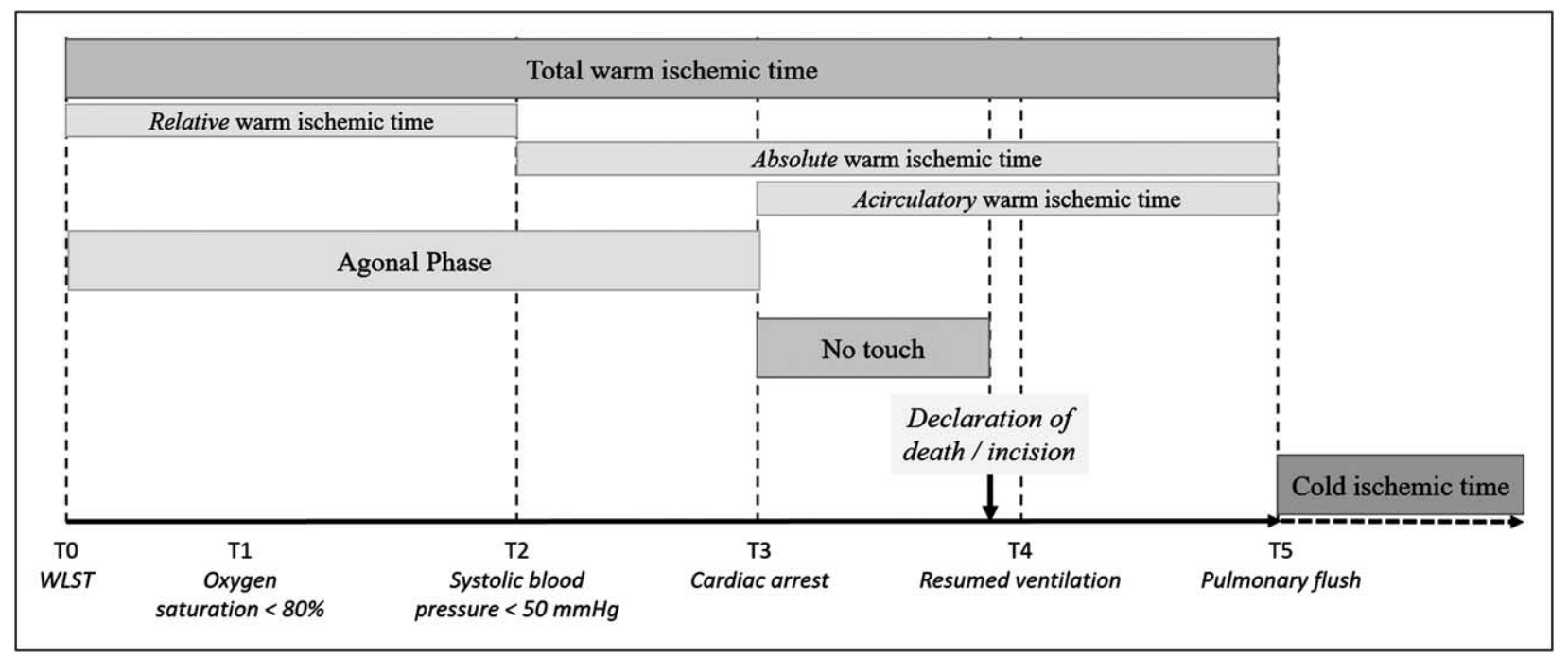

FIGURE 1. Schematic illustration of different time points and intervals related to controlled donation after circulatory death procedure. WLST, withdrawal of life-sustaining therapy.

The first two represent $\mathrm{uDCD}$ donors, the third and fourth a controlled type of DCD (cDCD). An uDCD is defined as unexpected death in which the organs could be considered for transplantation if the

Table 1. Original Maastricht classification of donation after circulatory death [48]

\begin{tabular}{lll}
\hline Category & Definition \\
\hline Uncontrolled & I & Death on arrival \\
& II & Unsuccessful resuscitation \\
Controlled & III & Awaiting cardiac arrest \\
& IV & Unexpected cardiac arrest in heart-beating donor
\end{tabular}

relatives are consented in time and the lungs are adequately preserved in the body. In case of cDCD the logistics for procurement, preservation and allocation could be organized in advance $[35,36]$.

Over the years, several subclassifications as well as a category $\mathrm{V}$ - donation after euthanasia - were added (Table 2) $[49,50]$. The section of the European Society for Organ Transplantation focusing on Ethical, Legal and Psychosocial Aspects of organ Transplantation (ELPAT) deceased donation working group defined an alternative uncontrolled category $\mathrm{V}$ as 'unexpected circulatory death in critically ill patients' [51].

\section{CLINICAL EXPERIENCE}

Over the last decade, barriers regarding DCD donation have been overcome by several centers, increasing the worldwide experience.

Table 2. Modified Maastricht classification of donation after circulatory death [50]

\begin{tabular}{|c|c|c|c|c|}
\hline \multirow{2}{*}{$\begin{array}{l}\text { Category } \\
\text { Uncontrolled }\end{array}$} & \multirow[b]{2}{*}{ I } & \multirow{2}{*}{$\begin{array}{l}\text { Definition } \\
\text { Found dead }\end{array}$} & \multicolumn{2}{|c|}{ Subclassification } \\
\hline & & & la & Out-of-hospital \\
\hline & & & $\mathrm{lb}$ & In hospital \\
\hline & $\|$ & Witnessed cardiac arrest & lla & Out-of-hospital \\
\hline & & & $\mathrm{llb}$ & In hospital \\
\hline \multirow[t]{6}{*}{ Controlled } & III & Planned WLST/expected circulatory death & Illa & $\ln I C U$ \\
\hline & & & IIlb & $\ln O R$ \\
\hline & IV & Cardiac arrest while brain death prior to organ recovery & $\mathrm{IVa}$ & Unexpected in ICU \\
\hline & & & $\mathrm{IVb}$ & Expected in OR/ICU \\
\hline & V & Medically assisted circulatory death/euthanasia & $\mathrm{Va}$ & Out-of-OR \\
\hline & & & $\mathrm{Vb}$ & $\ln O R$ \\
\hline
\end{tabular}

ICU, intensive care unit; OR, operating room; WLST, withdrawal of life-sustaining therapy. 


\begin{tabular}{lc}
\hline Table 3. Standard criteria for lung donation \\
\hline Age & $<65$ years \\
Smoking & $<20$ pack years \\
Chest radiograph & clear \\
Mechanical ventilation & $<5$ days \\
Blood transfusion & $<5-\mathrm{U}$ red blood cells \\
Oxygenation & $\mathrm{PaO}_{2}>300 \mathrm{mmHg}$
\end{tabular}

\section{Barriers to implement donation after circulatory death}

It remains surprising that DCD LTx implementation has not found more widespread application. Reasons for this underutilization are multifactorial. The ISHLT DCD working group reported that $85 \%$ of the participants mentioned complex logistics and absence of DCD-related protocols as the primary reasons for not using DCD [52]. Other barriers are regulations, fear of public disapproval, lack of surgical expertise, lung quality concerns, declined premortem evaluation, inability to evaluate lungs in a controlled fashion, financial challenges and possibility of aborted procurement [53].

We believe that the procedural complexity should not be overrated; once the ventilation is restored, perfusion, dissection and preservation are the same as for DBD. Aborted DCD procurement - or the so-called dry-run - on the other hand have been reported to be as high as $40 \%[19,27]$. Although scoring systems were developed to predict which patients could potentially become DCD donors, the scoring efficacy lacks scientific accuracy [27].

\section{Donation after circulatory death lung criteria and protocols}

For DCD donor selection, most centers apply internationally agreed DBD donor criteria (Table 3).

To further increase the donor pool, centers also accept more extended-criteria donors (ECD). Procedural criteria on the other hand are center-specific and might play a decisive role in whether or not to accept DCD lung allografts. Examples of this are the location of the WLST (ICU versus operating room), the comfort therapy administered by the treating physician, allowed WIT and agonal phase, withdrawal of tracheal tube, time of reventilation, notouch period and EVLP possibility [4,5,54"].

Various ethical frameworks for premortem management are used. In general, it is stated that any intervention that may accelerate death or cause potential harm is considered unacceptable. Administration of heparin is one example. In a DCD pig model Sanchez et al. showed that premortem heparin administration did improve EVLP evaluation by possibly maintaining endothelial homeostasis [55]. In another pig experiment, Keshava et al. [56] showed no difference in thrombus formation after flushing of the recovered lungs. To date, no comparative clinical study was performed and centers with or without heparin administration have reported equally good outcome [20].

More important is the appropriate treatment of a patient until death. Therefore, we would recommend continuous protective lung ventilation (tidal volume: $6-8 \mathrm{ml} / \mathrm{kg}$ ideal body weight, peak endexpiratory pressure (PEEP): $5-7 \mathrm{cmH}_{2} \mathrm{O}$ ), performing adequate bronchoscopy and naso-gastric tube placement to prevent aspiration.

\section{Clinical experience with uncontrolled donation after circulatory death}

Experience with uDCD has been limited. Major concerns are that the exact length of postmortem WIT is unknown and that organ function cannot be assessed in advance [5]. Therefore, it is strongly recommended that the lungs should be properly evaluated with EVLP to reduce the risk of primary nonfunction and primary graft dysfunction (PGD) [57].

Currently, Madrid published the largest experience of 29 cases with an overall hospital mortality of $17 \%$ and PGD3 of $38 \%$ [58].

\section{Clinical experience with controlled type of donation after circulatory death}

The advantage of a cDCD setting is that premortem assessment can be performed in the same way as for $\mathrm{DBD}$, that the WIT is known, that the lungs can be inspected in situ and preserved in a standard fashion. If the WLST is performed in the operating room, WIT will remain limited (10-15 min). In general, longer cold ischemic time (CIT) is noticed in DCD compared with DBD donors. This is explained by the fact that DCD lungs are accepted after perfusion, whereas DBD lungs could already be evaluated in situ before cold flush and anesthesia in the recipient can already be induced. A second reason is more particular to Eurotransplant allocation rules, which state that DCD lungs cannot be offered until $4 \mathrm{~h}$ before the procedure. This might create logistical problems with no operating room available for the recipient.

Over the last decade, several centers have reported their single-center experience $[9,13-$ $23,24 ", 25,26^{\prime \prime}, 27,28,29 \mathbf{*}^{-\prime}$. In most reports, data were compared with DBD. In general, results were excellent with most studies confirming that outcome after LTx from CDCD is the same as for DBD. We summarize the largest series in Table 4, describing 
Table 4. Studies reporting on lung transplantation from controlled donation after circulatory death donor

\begin{tabular}{|c|c|c|c|c|c|c|c|c|c|c|c|c|c|}
\hline \multirow[b]{3}{*}{ Reference } & \multirow[b]{3}{*}{ Location } & \multirow[b]{3}{*}{ Study design } & \multirow[b]{3}{*}{ DCD/DBD } & \multicolumn{10}{|c|}{ Outcome } \\
\hline & & & & \multicolumn{2}{|c|}{ PGD } & \multicolumn{5}{|c|}{$\%$ overall patient survival DCD/DBD } & \multicolumn{3}{|c|}{$\begin{array}{l}\% \text { CLAD free survival } \\
\text { DCD/DBD }\end{array}$} \\
\hline & & & & $\%$ DCD $/ \%$ DBD & Definition & 1-year & 3-year & 5 -year & 7-year & 10-year & 3-year & 5-year & 7-year \\
\hline Mason et al. [13] & OPTN, USA & Multicenter retrospective & $36 / 14903$ & NR & & $87 / 69$ & & & & & & & \\
\hline Puri et al. [14] & $\begin{array}{l}\text { St. Louis, Missouri, } \\
\text { USA }\end{array}$ & Single-center retrospective & $11 / 282$ & $36 / N R$ & $\begin{array}{l}\text { Grade 3, undefined } \\
\text { timepoint }\end{array}$ & $82 / 89$ & & & & & & & \\
\hline $\begin{array}{l}\text { De Oliveira et al. } \\
\text { [15] }\end{array}$ & $\begin{array}{l}\text { Wisconsin, } \\
\text { Wisconson, USA }\end{array}$ & Single-center retrospective & $18 / 406$ & $33 / 26$ & $\begin{array}{c}\text { Grade } 2 \text { or } \\
3 \text { within } 72 \mathrm{~h}\end{array}$ & $88 / 88$ & $82 / 73$ & $82 / 63$ & & & $80 / 75$ & $72 / 58$ & \\
\hline $\begin{array}{l}\text { Van De Wauwer } \\
\text { et al. [16] }\end{array}$ & $\begin{array}{l}\text { Groningen, The } \\
\text { Netherlands }\end{array}$ & Single-center retrospective & $35 / 77$ & $\begin{array}{c}24 / 25,9 / 16,3 / \\
10 \text { and } 6 / 11\end{array}$ & $\begin{array}{l}\text { Grade } 3 \text { at } 0,24, \\
48 \text { and } 72 h\end{array}$ & $91 / 91$ & $85 / 76$ & $73 / 66^{a}$ & & & & & \\
\hline $\begin{array}{l}\text { De Vleeschauwer } \\
\text { et al. [17] }\end{array}$ & Leuven, Belgium & Single-center retrospective & $21 / 154$ & $\begin{array}{c}55 / 55^{\mathrm{b}}, 12 / 22^{\mathrm{b}} \\
10^{\prime} / 12^{\mathrm{b}}\end{array}$ & $\begin{array}{l}\text { Grade } 3 \text { at } 0 \\
24 \text { and } 48 \mathrm{~h}\end{array}$ & & $95 / 91$ & $71 / 75$ & & & $70 / 82^{b}$ & & \\
\hline Zych et al. [18] & $\begin{array}{l}\text { Harefield, London, } \\
\text { UK }\end{array}$ & Single-center retrospective & $26 / 131$ & $\begin{array}{c}25 / 12,4 / 6 \\
4 / 10,4 / 6\end{array}$ & $\begin{array}{l}\text { Grade } 3 \text { at } 0 \\
24,48 \text { and } 72 \mathrm{~h}\end{array}$ & $89 / 87$ & $82 / 75$ & & & & $83 / 81$ & & \\
\hline Levvey et al. [9] & $\begin{array}{l}\text { Melbourne, } \\
\text { Brisbane, Perth, } \\
\text { Sidney, Australia }\end{array}$ & Multicenter retrospective & $72 / 503$ & $\begin{array}{l}21 / N R \text { and } \\
8 / N R\end{array}$ & $\begin{array}{l}\text { Grade } 2 \text { and } \\
3 \text { at } 24 \mathrm{~h}\end{array}$ & $97 / 90$ & & $90 / 61^{c}$ & & & & & \\
\hline Mason et al. [19] & $\begin{array}{l}\text { Cleveland, Ohio, } \\
\text { USA }\end{array}$ & Single-center retrospective & $32 / 573$ & $\begin{array}{l}3 / N R, 3 / N R \\
6 / N R, 6 / N R\end{array}$ & $\begin{array}{l}\text { Grade } 3 \text { at } 0 \\
24,48 \text { and } 72 \mathrm{~h}\end{array}$ & $91 / \mathrm{NR}$ & $71 / N R$ & & & & & & \\
\hline Cypel et al. [20] & $\begin{array}{l}\text { ISHLT, DCD registry } \\
(10 \text { centers })\end{array}$ & Multicenter retrospective & $306^{d} / 3992$ & NR & & $89 / 88$ & & $61 / 61$ & & & & & \\
\hline Machuca et al. [21] & Toronto, Canada & Single-center retrospective & $55 / 570$ & $11 /$ NR & Grade 3 at $72 \mathrm{~h}$ & $85 / 86$ & & $54 / 62$ & & & & & \\
\hline $\begin{array}{l}\text { Sabashnikov et al. } \\
\text { [22] }\end{array}$ & $\begin{array}{l}\text { Harefield, London, } \\
\text { UK }\end{array}$ & $\begin{array}{l}\text { Single-center retrospective, } \\
\text { propensity-matched }\end{array}$ & $60 / 120$ & $\begin{array}{l}27 / 11,9 / 5 \\
5 / 7 \text { and 5/9 }\end{array}$ & $\begin{array}{l}\text { Grade } 3 \text { at } 0 \\
24,48 \text { and } 72 \mathrm{~h}\end{array}$ & $86 / 84$ & $61 / 77$ & $51 / 66^{e}$ & $51 / 66^{e}$ & & $72 / 88$ & $47 / 79^{e}$ & $31 / 59^{e}$ \\
\hline Ruttens et al. [23] & Leuven, Belgium & Single-center retrospective & $59 / 331$ & $44 / 47$ & Grade 3 within $72 \mathrm{~h}$ & $87 / 91$ & $76 / 83$ & $71 / 78$ & & & $82 / 85$ & $79 / 68$ & \\
\hline $\begin{array}{l}\text { Van Suylen et al. } \\
{\left[24^{-}\right]}\end{array}$ & $\begin{array}{l}\text { Groningen, Utrecht, } \\
\text { Rotterdam, The } \\
\text { Netherlands }\end{array}$ & $\begin{array}{l}\text { Multicenter retrospective, } \\
\text { propensity-matched }\end{array}$ & $130 / 130$ & $8 / 8$ and $8 / 6$ & $\begin{array}{c}\text { Grade } 3 \text { at } 48 \\
\text { and } 72 \mathrm{~h}\end{array}$ & $87 / 82$ & $80 / 73$ & $69 / 68$ & & & $88 / 88$ & $76 / 71$ & \\
\hline Inci et al. [25] & Zürich, Switzerland & Single-center retrospective & $21 / 130$ & $\begin{array}{l}26 / 48,16 / 10 \\
16 / 14 \text { and } 15 / 14\end{array}$ & $\begin{array}{l}\text { Grade } 3 \text { at } 0 \\
24,48 \text { and } 72 \mathrm{~h}\end{array}$ & $100 / 85$ & $80 / 69$ & & & & $68 / 62$ & & \\
\hline \multirow[t]{3}{*}{$\begin{array}{l}\text { Villavicencio et al. } \\
{\left[26^{\mathbf{E}}\right]}\end{array}$} & OPTN, USA & $\begin{array}{l}\text { Multicenter retrospective, } \\
\text { propensity-matched }\end{array}$ & $389 / 20516$ & $N R$ & & $86 / 85$ & & $59 / 55$ & & $33 / 30$ & & & \\
\hline & & & $311 / 311$ & & & $87 / 88$ & $68 / 71$ & & & & & & \\
\hline & $\begin{array}{l}\text { Boston, } \\
\text { Massachusetts, } \\
\text { USA }\end{array}$ & Single-center retrospective & $15 / 113$ & $\begin{array}{l}40 / 9^{c}, 13 / 11 \\
20 / 7 \text { and } 10 / 10\end{array}$ & $\begin{array}{l}\text { Grade } 2 \text { or } 3 \text { at } 0 \\
24,48 \text { and } 72 \mathrm{~h}\end{array}$ & $86 / 92$ & $86 / 63$ & & & & & & \\
\hline Costa et al. [27] & $\begin{array}{l}\text { New York, New } \\
\text { York, USA }\end{array}$ & Single-center retrospective & $46 / 237$ & $\begin{array}{c}26 / 19,20 / 19 \\
\text { and } 13 / 17\end{array}$ & $\begin{array}{c}\text { Grade } 3 \text { at } \\
24,48 \text { and } 72 \mathrm{~h}\end{array}$ & $91 / 91$ & $78 / 75$ & & & & & & \\
\hline Barbero et al. [28] & $\begin{array}{l}\text { Papworth, } \\
\text { Cambridge, UK }\end{array}$ & Single-center retrospective ${ }^{f}$ & $23 / 163$ & $26 / 21$ and $17 / 12$ & $\begin{array}{l}\text { Grade } 2 \text { or } 3 \text { at } \\
24 \text { and } 72 \mathrm{~h}\end{array}$ & $75 / 82$ & & $51 / 61$ & & & $82 / 78$ & $83 / 42^{9}$ & \\
\hline $\begin{array}{l}\text { Van Raemdonck } \\
\text { et al. [29"'] }\end{array}$ & $\begin{array}{l}\text { ISHLT, DCD registry } \\
\text { (23 centers) }\end{array}$ & Multicenter retrospective & $1090 / 10426$ & NR & & $89 / 88$ & & $63 / 61$ & & & $59 / 59$ & $41 / 39^{b}$ & \\
\hline
\end{tabular}

CLAD, chronic lung allograft dysfunction; DBD, donation after brain death; DCD, donation after circulatory death; ISHLT, International Society for Heart and Lung Transplantation; NR, not reported; OPTN, Organ Procurement and Transplantation Network; PGD, primary graft dysfunction.

aOnly two DCD patients at risk.

bestimated from figure.

Considered significant; $P$ less than 0.05 .

Including $4 \%$ DCD IV and $1 \%$ DCD V.

eFive or less DCD patients at risk.

Survival analysis in subgroup of bilateral lung transplants (14 DCD and 133 DBD).

gOnly four DCD patients at risk.

\section{Copyright @ 2019 Wolters Kluwer Health, Inc. Unauthorized reproduction of this article is prohibited.}


PGD ratio, overall survival and chronic lung allograft dysfunction-free survival.

The significant differences between DCD and DBD were 5-year patient survival from the Australian cohort which revealed a $90 \%$ survival for the DCD versus $61 \%$ for the DBD cohort [9]; the Boston experience only showed worse PGD at time 0 for DCD in comparison with DBD [26"]; and Sabashnikov et al. showed a shorter bronchiolitis obliteranssyndrome (BOS)-free survival in the DCD group, although after 4 years post-transplantation only five DCD patients were considered at-risk [22]. Furthermore, a meta-analysis revealed no difference between DBD and DCD LTx in regard to length of stay, acute rejection or airway complications [4]. The first analysis of the ISHLT DCD registry only revealed a 2-day longer stay following DCD LTX $(P=0.016)$, which was confirmed in the cohort described by Costa (22 days for DCD versus 18 days for DBD, $P=0.0014$ ) [20,27]. In 2018, Villavicencio et al. performed a multivariable regression analysis of the OPTN data for 25 recipient and donor characteristics, revealing no association between DCD and increased mortality in comparison with DBD [26"]. In 2016, Sabashnikov et al. reported the longest follow-up (7 years) comparing DCD with DBD, concluding that DCD lungs had a predisposition for developing BOS [22]. However, at 7-year follow-up only one DCD was included. An update by the ISHLT DCD registry is expected in 2019, comparing 1090 DCD versus 10426 DBD LTx [29"']. Five-year patient and BOS-free survival showed no difference between both groups. In future, more studies analyzing long-term outcome are needed.

\section{Donation after circulatory death V, following euthanasia}

After the first case of organ donation following euthanasia in Belgium in 2005, also the Netherlands and Canada created a legal framework for DCD V $[59,60]$. In general, only patients suffering from a debilitating benign disease like neurological or muscular disorder are considered for organ donation. A clear separation between the euthanasia request, the euthanasia procedure and the procurement is of utmost importance to exclude any conflict of interest between donor and recipient and between the teams involved. This strict separation is also mandatory to maintain public trust $[60,61]$.

The first LTx from a DCD V donor was performed in Leuven in 2007 [59]. Until now, 14 double lungs from DCD V donors have been transplanted in Leuven, representing $12 \%$ of the DCD and $2 \%$ of the institutional LTx activity. With more LTx from DCD $\mathrm{V}$ performed in future it will become interesting to investigate if there is a difference in outcome between DCD V, DCD III and DBD. Although donors after euthanasia resemble DCD III and their organs suffer a period of inevitable warm ischemia, they are usually not supported on a ventilator and the mode of death is completely different compared with ventilator switch-off awaiting hypoxic cardiac arrest. These donors do not experience an agonal phase prior to circulatory arrest as seen in donors dying from hypoxia or from cardiogenic/hypovolemic shock. There is also no catecholamine storm as observed in DBD donors. These benefits could lead to a better outcome.

A recent perspective article explored the ethical and legal considerations of euthanasia by organ donation for patients who wish to donate their organs as in a 'living organ donation setting' [62"]. This procedure would omit any type of WIT. Currently no ethical or legal framework is available to allow this.

\section{EX-VIVO LUNG PERFUSION}

Selective use of EVLP is part of the DCD III program in most centers, however not a prerequisite. In our opinion, EVLP is not necessary in every case since excellent results were obtained without the routine use of EVLP. In the ISHLT 2015 report, only 12\% of the DCD cases underwent normothermic EVLP [20]. This low percentage may reflect lack of EVLP-availability at the time of data collection, but also the perception of each center of the benefit of EVLP in assessing CDCD. However, these results have also shown that EVLP is a safe modality with the potential to increase confidence in DCD lungs translating to excellent outcomes. Furthermore, we believe that selective EVLP may help to better assess functionally ECD lungs and may help to safely accept longer agonal phases or expected longer ischemic times. Possible indications for EVLP may be: $\mathrm{PaO}_{2}$ less than $300 \mathrm{mmHg}$, edematous lungs, massive blood transfusion ( $>10 \mathrm{U}$ ), poor lung compliance, suspicion of aspiration or pulmonary infection.

In 2017, the University of Alberta reported on seven successful DCD LTx that underwent portable normothermic EVLP (OCS Lung, Transmedics, Inc., Andover, Massachusetts, USA) [63"]. In comparison with non-DCD lungs, this EVLP cohort had a significant shorter CIT, a lower PGD grade and higher P : F ratio at $72 \mathrm{~h}$ post-transplantation. In 2015, Toronto compared 28 DCD LTx with EVLP (Toronto EVLPsystem) versus 27 without EVLP, revealing no difference in survival but a significant shorter hospital stay for the EVLP group [21]. For uDCD, the results remain suboptimal and therefore EVLP is strongly recommended by the ISHLT DCD working group. 
Currently the final reports of two prospective multicenter clinical trials involving DCD LTx and EVLP are awaited; first, the aim of the EXPAND Lung Trial (OCS Lung, Transmedics, Inc.) is to assess the short-term clinical outcome of lungs from ECD (including DCD) that were normothermically preserved. 79 ECD were included, of which $33 \%$ were DCD LTx [64"']; and second, the NOVEL-extension trial (XVIVO XPS) aims to evaluate the outcome of EVLP in case of DCD LTx. 24 DCD-EVLP LTx were included. In comparison with DBD, there was no difference in PGD and the survival between EVLP recovered DCD, DBD allografts and non-EVLP controls [65"'].

These results confirm that EVLP is a safe platform that may further expand the donor pool by assessing questionable DCD lungs. EVLP will also further expand the donor pool as it is an ideal platform for therapeutic intervention (antibiotic, fibrinolytic therapy) and immunomodulation [66"].

\section{NORMOTHERMIC REGIONAL PERFUSION AND DONATION AFTER CIRCULATORY DEATH HEART PROCUREMENT: THE FUTURE CHALLENGES}

The application of extracorporeal circulation technology to DCD organ retrieval in the form of thoraco-abdominal normothermic regional perfusion (NRP) is believed to make a significant impact [67"-]. In this setting, DCD heart transplantation has been made possible in synergy with technological advances of ex-situ preservation [68"]. NRP enables conversion from a DCD to a DBD-type donor which offers the opportunity for a dynamic organ assessment in situ after death declaration and may lead to expansion of acceptance criteria as well as creating a window of opportunity for early interventions. However, this new logistic challenge should carefully be assessed. Each procurement will require a detailed discussion between the different teams about coordination, timings and preservation strategies.

\section{CONCLUSION}

A global implementation of DCD lung donation would significantly decrease the mortality on the waiting-list. Over the last 10 years, several centers and the ISHLT DCD registry reported their experience, showing that LTx from CDCD results in the same short-term and mid-term outcome as from DBD donors. It is advised that EVLP should be used for uDCD. Future research on EVLP, the long-term outcome after DCD and a detailed analysis of the agonal phase are warranted to further explore the true potential of DCD lung donation.

\section{Acknowledgements}

None.

\section{Financial support and sponsorship}

The current work was supported by the European Society of Thoracic Surgeons (ESTS) biology club fellowship and the European Society of Organ Transplantation (ESOT) fellowship.

\section{Conflicts of interest}

There are no conflicts of interest.

\section{REFERENCES AND RECOMMENDED READING}

Papers of particular interest, published within the annual period of review, have been highlighted as:

- of special interest

- of outstanding interest

1. Valapour M, Lehr CJ, Skeans MA, et al. OPTN/SRTR 2017 annual data report: - lung. Am J Transplant 2019; 19(Suppl 2):404-484.

The latest annual report by the Organ Procurement and Transplantation Network (OPTN) on lung transplant activities in the United States.

2. Chambers DC, Cherikh WS, Goldfarb SB, et al. The international thoracic

- organ transplant registry of the international society for heart and lung transplantation: thirty-fifth adult lung and heart-lung transplant report-2018; Focus theme: multiorgan transplantation. J Heart Lung Transplant 2018; 37:1169-1183.

The latest annual report by the International Society for Heart and Lung Transplantation (ISHLT) on lung transplantation (LTX) activities worldwide reported to the registry.

3. Israni AK, Zaun D, Rosendale JD, et al. OPTN/SRTR 2017 annual data report:

- deceased organ donation. Am J Transplant 2019; 19(Suppl 2):485-516.

The latest annual report by the OPTN on deceased organ donation activities in the United States.

4. Krutsinger $\mathrm{D}$, Reed RM, Blevins $\mathrm{A}$, et al. Lung transplantation from donation after cardiocirculatory death: a systematic review and meta-analysis. J Heart Lung Transplant 2015; 34:675-684.

5. Inci I. Donors after cardiocirculatory death and lung transplantation. J Thorac Dis 2017; 9:2660-2669.

6. Erasmus ME, Van Raemdonck D, Akhtar MZ, et al. DCD lung donation: donor criteria, procedural criteria, pulmonary graft function validation, and preservation. Transpl Int 2016; 29:790-797.

7. Halpern SD, Hasz RD, Abt PL. Incidence and distribution of transplantable organs from donors after circulatory determination of death in U.S. intensive care units. Ann Am Thorac Soc 2013; 10:73-80.

8. Newsletter Transplant 2018. 2019. Available at: https://www.edqm.eu/en/ reports-and-publications. [Accessed 21 February 2019].

9. Levvey BJ, Harkess M, Hopkins P, et al. Excellent clinical outcomes from a national donation-after-determination-of-cardiac-death lung transplant collaborative. Am J Transplant 2012; 12:2406-2413.

10. Organ procurement and transplantation network national data. 2018. Available at: https://optn.transplant.hrsa.gov/data/view-data-reports/national-data/. [Accessed 21 February 2019].

11. Eurotransplant data. 2018. Available at: https://www.eurotransplant.org/ $\mathrm{cms} /$ mediaobject.php?file $=803150+020288+$ Statistical+Report+2017+ \%28online\%2913.pdf. [Accessed 21 February 2019].

12. Dominguez-Gil $B$, Haase-Kromwijk $B$, Van Leiden $\mathrm{H}$, et al. Current situation of donation after circulatory death in European countries. Transpl Int 2011; $24: 676-686$.

13. Mason DP, Thuita L, Alster JM, et al. Should lung transplantation be performed using donation after cardiac death? The United States experience. J Thorac Cardiovasc Surg 2008; 136:1061-1066.

14. Puri V, Scavuzzo M, Guthrie $T$, et al. Lung transplantation and donation after cardiac death: a single-center experience. Ann Thorac Surg 2009; 88:1609-1614. 
15. De Oliveira NC, Osaki S, Maloney JD, et al. Lung transplantation with donation after cardiac arrest death donors: long-term follow-up in a single center. J Thorac Cardiovasc Surg 2010; 139:1306-1315.

16. Van De Wauwer $C$, Verschuuren $E A$, van der Bij W, et al. The use of nonheartbeating lung donors category III can increase the donor pool. Eur J Cardiothorac Surg 2011; 39:e175-e180.

17. De Vleeschauwer SI, Wauters S, Dupont LJ, et al. Medium-term outcome after lung transplantation is comparable between brain-dead and cardiac-dead donors. J Heart Lung Transplant 2011; 30:975-981.

18. Zych B, Popov AF, Amrani M, et al. Lungs from donation after circulatory death donors: an alternative source to brain-dead donors? Midterm results at a single institution. Eur J Cardiothorac Surg 2012; 42:542-549.

19. Mason DP, Brown CR, Murthy SC, et al. Growing single-center experience with lung transplantation using donation after cardiac death. Ann Thor Surg 2012; 94:406-412.

20. Cypel M, Levvey B, Van Raemdonck D, et al. International Society for Heart and Lung Transplantation donation after circulatory death registry report. J Heart and Lung Transplant 2015; 34:1278-1282.

21. Machuca $T N$, Mercier $O$, Collaud $S$, et al. Lung transplantation with donation after circulatory determination of death donors and the impact of ex vivo lung perfusion. Am J Transplant 2015; 15:993-1002.

22. Sabashnikov $A$, Patil NP, Popov $A-F$, et al. Long-term results after lung transplantation using organs from circulatory death donors: a propensity score-matched analysis. Eur J Cardiothorac Surg 2016; 49:46-53.

23. Ruttens $D$, Martens $A$, Ordies $S$, et al. Short- and long-term outcomes after lung transplantation from circulatory-dead donors: a single-center experience. Transplantation 2017; 101:2691-2694.

24. Van Suylen V, Luijk B, Hoek RAS, et al. A multicenter study on long-term outcomes after lung transplantation comparing donation after circulatory death and donation after brain death. Am J Transplant 2017; 17:2679-2686.

This is a multicenter study that reports on the 5-year LTx outcome following donation after circulatory death (DCD) compared to a propensity-matched donation after brain death (DBD) cohort.

25. Inci I, Hillinger S, Schneiter $D$, et al. Lung transplantation with controlled donation after circulatory death donors. Ann Thorac Cardiovasc Surg 2018; 24:296-302.

26. Villavicencio MA, Axtell $A L$, Spencer $P J$, et al. Lung transplantation from

- donation after circulatory death: United States and single-center experience. Ann Thorac Surg 2018; 106:1619-1627.

The retrospective study analyses the United States experience with LTx following DCD and performed a comparison with a propensity matched cohort of donation after brain-death.

27. Costa J, Shah L, Robbins $H$, et al. Use of lung allografts from donation after cardiac death donors: a single-center experience. Ann Thor Surg 2018; 105:271-278.

28. Barbero $C$, Messer $S$, Ali A, et al. Lung donation after circulatory determined death: a single-center experience. Eur J Cardiothorac Surg 2019; 55:309-315.

29. Van Raemdonck D, Keshavjee S, Levvey B, et al. 5-year results from the

- International Society for Heart and Lung Transplantation DCD lung transplant registry confirm excellent recipient survival from donation after circulatory death donors. J Heart Lung Transplant 2019; 38(Suppl 4):S103.

This abstract on the ISHLT DCD Registry reports on the largest multicenter retrospective analysis of LTx following DCD $(n=1090)$ versus DBD $(n=10,426)$. The full paper is awaited.

30. Hardy JD, Webb WR, Dalton ML Jr, Walker GR Jr. Lung homotransplantation in man. JAMA 1963; 186:1065-1074.

31. Egan TM, Lambert CJ Jr, Reddick R, et al. A strategy to increase the donor pool: use of cadaver lungs for transplantation. Ann Thor Surg 1991; 52:1113-1120.

32. Love RB, Stringham JC, Chomniak PN, et al. Successful lung transplantation using a nonheart-beating donor. J Heart Lung Transplant 1995; 14:S88.

33. D'Alessandro AM, Hoffmann RM, Knechtle SJ, et al. Controlled nonheart beating donors: a potential source of extrarenal organs. Transplant Proc 1995; 27:707-709.

34. Steen $S$, Sjöberg T, Pierre L, et al. Transplantation of lungs from a nonheartbeating donor. Lancet 2001; 357:825-829.

35. Van Raemdonck D, Rega FR, Neyrinck AP, et al. Non heart-beating donors. Semin Thorac Cardiovasc Surg 2004; 16:309-321.

36. Wigfield C. Donation after cardiac death for lung transplantation: a review of current clinical practice. Curr Opin Organ Transplant 2014; 19:455-459.

37. Koukoulis G, Caldwell $\mathrm{R}$, Inokawa $\mathrm{H}$, et al. trands in lung $\mathrm{pH}$ and $\mathrm{PO}_{2}$ after circulatory arrest: implications for nonheart beating donors and cell culture models of lung ischemia-reperfusion injury. J Heart Lung Transplant 2005; 24:2218-2225.

38. D'Armini AM, Roberts CS, Griffith PK, et al. When does the lung die? I. Histochemical evidence of pulmonary viability 'death'. J Heart Lung Transplant 1994; 13:741-747.

39. D'Armini AM, Tom EJ, Roberts CS, et al. When does the lung die? Time course of high energy phosphate depletion and relationship to lung viability after 'death'. J Surg Res 1995; 59:468-474.

40. Van Raemdonck DE, Jannis NC, De Leyn PR, et al. Warm ischemic tolerance in collapsed pulmonary grafts is limited to $1 \mathrm{~h}$. Ann Surg 1998; 228:788-796
41. Van Raemdonck DR, Jannis NC, De Leyn PR, et al. Alveolar expansion itself but not continuous oxygen supply enhances postmortem preservation of pulmonary grafts. Eur J Cardiothorac Surg 1998; 13:431-440.

42. Charles EJ, Hunter Mehaffey J, Huerter ME, et al. Ex vivo assessment of

- porcine donation after circulatory death lungs that undergo increasing warm ischemia times. Transplant Direct 2018; 4:e405.

The experimental study in pigs reports on the outcome of lung function after $4 \mathrm{~h}$ of ex vivo lung perfusion following different periods of warm ischemia after circulatory death.

43. Totsuka E, Fung JJ, Urakami A, et al. Influence of donor cardiopulmonary arrest in human liver transplantation: possible role of ischemic preconditioning. Hepatology 2000; 31:577-580.

44. Avlonitis VS, Fisher AJ, Kirby JA, Dark JH. Pulmonary transplantation: the role of brain death in donor lung injury. Transplantation 2003; 75:1928-1933.

45. Kang $\mathrm{CH}$, Anraku M, Cypel $\mathrm{M}$, et al. Transcriptional signatures in donor lungs from donation after circulatory death vs after brain death: a functional pathway analysis. J Heart Lung Transplant 2011; 30:289-298.

46. Levvey B, Keshavjee S, Cypel M, et al. Influence of lung donor agonal warm

-1 ischemic times on early mortality: analyses from the ISHLT DCD lung transplant registry. J Heart and Lung Transplant 2019; 38:26-34.

The article from the ISHLT DCD registry reports on a multicenter analysis investigating the correlation between the warm ischemic agonal phase in DCD and the outcome after LTx.

47. Reeb J, Keshavjee S, Cypel M. Successful lung transplantation from a donation after cardiocirculatory death donor taking more than $120 \mathrm{~min}$ to cardiac arrest after withdrawal of life support therapies. J Heart Lung Transplant 2016; 35:258-259.

48. Kootstra G, Daemen JH, Oomen AP. Categories of nonheart beating donors. Transplant Proc 1995; 27:2893-2894.

49. Thuong $M$, Ruiz $A$, Evrard $P$, et al. New classification of donation after circulatory death donors definitions and terminology. Transpl Int 2016; 29:749-759.

50. Detry $\mathrm{O}$, Le Dinh $\mathrm{H}$, Noterdaeme $T$, et al. Categories of donation after cardiocirculatory death. Transplant Proc 2012; 44:1189-1195.

51. Gardiner $D$, Wind $T$, Cole $B$, et al. European Vignettes in donation after circulatory death. Prog Transplant 2017; 27:286-290.

52. Cypel M, Levvey $B$, Van Raemdonck $D$, et al. Lung transplantation using controlled donation after circulatory death donors: trials and tribulations. J Heart Lung Transplant 2016; 35:146-147.

53. Mooney JJ, Hedlin $\mathrm{H}$, Mohabir PK, et al. Lung quality and utilization in controlled donation after circulatory determination of death within the United States. Am J Transplant 2016; 16:1207-1215.

54. Snell Gl, Levvey $B J$, Levin $\mathrm{K}$, et al. Donation after brain death versus donation

- after circulatory death: lung donor management issues. Semin Respir Crit Care Med 2018; 39:138-147.

The review article from the Alfred Hospital in Melbourne, Australia elegantly highlights the controversies of DCD versus DBD and LTx as well as the areas for future development and research.

55. Sanchez PG, Bittle GJ, Williams K, et al. Ex vivo lung evaluation of prearrest heparinization in donation after cardiac death. Ann Surg 2013; 257:534-541.

56. Keshava HB, Farver CF, Brown CR, et al. Timing of heparin and thrombus formation in donor lungs after cardiac death. Thorac Cardiovasc Surg 2013; 61:246-250.

57. Egan TM, Requard JJ 3rd. Uncontrolled donation after circulatory determination of death donors (uDCDDs) as a source of lungs for transplant. Am J Transplant 2015; 15:2031-2036.

58. Gomez-de-Antonio $\mathrm{D}$, Campo-Cañaveral JL, Crowley $\mathrm{S}$, et al. Clinical lung transplantation from uncontrolled nonheart-beating donors revisited. J Heart Lung Transplant 2012; 31:349-353.

59. Van Raemdonck D, Verleden GM, Dupont L, et al. Initial experience with transplantation of lungs recovered from donors after euthanasia. Appl Cadiopulm Pathophysiol 2011; 15:38-48.

60. Bollen J, ten Hoopen R, Ysebaert D, et al. Legal and ethical aspects of organ donation after euthanasia in Belgium and the Netherlands. J Med Ethics 2016; $42: 486-489$

61. Van Raemdonck D, Neyrinck A. Euthanasia patients should be accepted as organ donors in states with existing legislation. Ann Thor Surg 2016; 102:1787-1788.

62. Bollen JAM, Shaw D, de Wert G, et al. Euthanasia through living organ

- donation: ethical, legal and medical challenges. J Heart Lung Transplant 2019; 38:111-113.

The letter describes the hypothetical option of euthanasia by living DCD

63. Luc JGY, Jackson K, Weinkauf JG, et al. Feasibility of lung transplantation from

- donation after circulatory death donors following portable ex vivo lung perfusion: a pilot study. Transplant Proc 2017; 49:1885-1892.

The institutional report from the University of Alberta, Canada, describes their experience with the use of ex-vivo lung perfusion for DCD donors.

64. Loor G, Warnecke G, Villavicenvio M, et al. Results of the OCS Lung

- EXPAND International Trial using portable normothermic OCS lung perfusion system (OCS) to recruit and evaluate extended criteria donor (ECD) lungs. J Heart Lung Transplant 2018; 37(Suppl 4):S147.

The abstract reports the final results of the OCS Lung EXPAND Trial, a prospective trial to evaluate the use of normothermic ex-vivo lung perfusion (EVLP) (OCS Transmedics) for expanded criteria donors, including DCD. 
65. Whitson BA, Shukrallah B, Mulligan MS, et al. Ex-vivo lung perfusion in - donation after circulatory death lung transplantation increases donor utilization: analysis of the NOVEL extension trial. J Heart Lung Transplant 2018; 37(Suppl 4):S147-S148.

The abstract reports the preliminary results of the NOVEL extension trial, a multicenter clinical trial comparing the outcome between lung transplant recipients who received lungs after the use of normothermic EVLP (XVIVO XPS platform) for expanded criteria donors, including DCD.

66. Van Raemdonck D, Rega F, Rex S, Neyrinck A. Machine perfusion of thoracic - organs. J Thorac Dis 2018; 10:S910-S923.

Narrative review that highlights the current experience and future potential of machine perfusion in thoracic organ preservation.
67. Tsui SSL, Oniscu GC. Extending normothermic regional perfusion to the -1. thorax in donors after circulatory death. Curr Opin Organ Transplant 2017; 22:245-250.

The article describes a new technique of in-situ resuscitation of the arrested heart using extended normothermic regional (thoraco-abdominal) perfusion in DCD.

68. Messer S, Page A, Colah S, et al. Human heart transplantation from donation - after circulatory-death donors using normothermic regional perfusion and cold storage. J Heart Lung Transplant 2018; 37:865-869.

The article from Papworth Hospital, Cambridge, United Kingdom, describes their method of normothermic regional perfusion and cold storage for DCD heart transplantation. 